\title{
PENGARUH BUAH NANAS (ANANAS COMOSUS L. MERR) TERHADAP PENINGKATAN PH SALIVA YANGTERPAPAR MINUMAN BERKARBONASI
}

\author{
Ahmad Syauqy ${ }^{1}$, Hanina ${ }^{2}$ \\ 1,2Prodi Kedokteran FKIK UNJA, Jl. Let Jen Soeprapto Gedung ex SLB Jambi \\ Email: asqyibi30@gmail.com
}

\begin{abstract}
Background: Pineapple (Ananas comosus L. Merr) has a myriad of properties that are very good for health because pineapple contains $90 \%$ water and is rich in potassium, calcium, iodine, sulfur, and Chlorine. Pineapple greatly help clean the teeth of leftovers that stick to the teeth and can increase the production of saliva (saliva) and affect the level of acidity of saliva. The purpose of this study was to determine the effect of pineapple on the $\mathrm{pH}$ of saliva that has been exposed to carbonated beverages.
\end{abstract}

Methods: This was an experimental study using a randomized controlled design group design. Samples were students of medical study program is divided into a control group and the treatment group. Salivary $\mathrm{pH}$ test results two groups will be compared and statistically tested using the Independent Sample T-Test to find the difference in average increase (difference) $\mathrm{pH}$ control group (the group not given the pineapple) and the treatment group (group given pineapple).

Results: Statistical tests conveniently indicates there are significant differences between the control group to the treatment group with a $P$ value of 0.000 .

Conclusion: Consumption of pineapple fruit can lower the $\mathrm{pH}$ of saliva after exposure to carbonated beverages.

Keywords: $\mathrm{pH}$, Saliva, Pineapple, Carbonation

\section{ABSTRAK}

Latar Belakang: Buah nanas (Ananas comosus L. Merr) memiliki segudang khasiat yang sangat baik untuk kesehatan karena nanas memiliki kandungan 90\% air dan kaya akan Kalium, Kalsium, lodium, Sulfur, dan Khlor. Nanas sangat membantu membersihkan gigi dari sisa makanan yang menempel pada gigi serta dapat meningkatkan produksi saliva (air liur) dan mempengaruhi tingkat keasaman suatu saliva. Tujuan dari penelitian ini adalah untuk mengetahui pengaruh buah nanas terhadap pH saliva yang telah terpapar minuman berkarbonasi. Metode Penelitian: Penelitian ini merupakan penelitian experimental menggunakan rancangan randomized controlled group design. Sampel penelitian adalah mahasiswa prodi kedokteran yang terbagi dalam kelompok kontrol dan kelompok perlakuan. Hasil pemeriksaan $\mathrm{pH}$ saliva kedua kelompok akan dibandingkan dan diuji secara statistik menggunakan Independent Sample T-Test untuk mencari perbedaan rata-rata peningkatan (selisih) $\mathrm{pH}$ kelompok kontrol (kelompok yang tidak di beri nanas) dan kelompok perlakuan (kelompok yang diberi nanas).

Hasil: Uji statistik meunjukkan terdapat perbedaan yang signifikan antara kelompok kontrol dengan kelompok perlakuan dengan nilai $P$ 0,000.

Kesimpulan: Konsumsi buah nanas dapat menurunkan pH saliva setelah terpapar minuman berkarbonasi.

Kata kunci : pH, Saliva, Nanas, Karbonasi 


\section{PENDAHULUAN}

Buah nanas (Ananas comosus L. Merr) memiliki segudang khasiat yang sangat baik untuk kesehatan karena nanas memiliki kandungan $90 \%$ air dan kaya akan Kalium, Kalsium, lodium, Sulfur, dan Khlor. Selain itu nanas (Ananas comosus L. Merr) juga kaya akan Biotin, Vitamin B12, Vitamin E serta Enzim Bromelin yang memiliki efek bakteriostatik. Nanas (Ananas comosus L. Merr) yang kaya akan Asam Sitrat, serat dan air sangat membantu membersihkan gigi dari sisa makanan yang menempel pada gigi serta dapat meningkatkan produksi saliva (air liur) dan mempengaruhi tingkat keasaman suatu saliva. ${ }^{1}$

$\mathrm{pH}$ (Potential of Hydrogen) saliva adalah satuan yang digunakan untuk mengukur tingkat keasaman suatu saliva. Produksi aliran saliva (laju aliran saliva), mikroorganisme rongga mulut dan kapasitas buffer saliva merupakan salah satu faktor yang dapat mempengaruhi perubahan $\mathrm{pH}$ saliva. Normalnya $\mathrm{pH}$ saliva akan kembali normal dalam waktu 30-60 menit dari konsumsi terakhir. Lamanya waktu penetralan $\mathrm{pH}$ saliva meningkatkan resiko terbentuknya karies gigi. ${ }^{2}$

Penurunan $\mathrm{pH}$ saliva mencapai $\mathrm{pH}$ kritis demineralisasi gigi-geligi akan meningkat, sedangkan pada kenaikan $\mathrm{pH}$ saliva hingga melebihi batas normal dapat menyebabkan suasana basa dan meningkatkan pembentukan karang gigi. ${ }^{3}$ Penelitian oleh Rahmawati tahun 2015 menyimpulkan bahwa mengkonsumsi minuman berkarbonasi yang terlalu banyak dalam sehari akan mengakibatkan penurunan $\mathrm{pH}$ saliva dibawah normal karena minuman berkarbonasi mengandung karbohidrat dan gula yang akan difermentasi menjadi asam oleh mikroorganisme rongga mulut. ${ }^{4}$ Berdasarkan peneltian Aritonang tahun 2014 didapat hubungan frekuensi minum softdrink terhadap $\mathrm{pH}$ saliva dimana semakin tinggi frekuensi mengkonsumsi minuman softdrink maka semakin rendah angka pH saliva. ${ }^{5}$

Berdasarkan uraian diatas, peneliti tertarik untuk melakukan penelitian tentang pengaruh buah nanas (Ananas comosus L. Merr) terhadap $\mathrm{pH}$ saliva yang telah terpapar minuman berkarbonasi.

\section{METODE PENELITIAN}

Penelitian ini merupakan penelitian experimental. menggunakan rancangan randomized controlled group design. Sampel penelitian adalah mahasiswa prodi kedokteran yang terbagi dalam kelompok kontrol dan kelompok perlakuan. Hasil pemeriksaan $\mathrm{pH}$ saliva kedua kelompok akan dibandingkan dan diuji secara statistik menggunakan Independent Sample T-Test untuk mencari perbedaan rata-rata peningkatan (selisih) $\mathrm{pH}$ kelompok kontrol (kelompok yang tidak di beri nanas) dan kelompok perlakuan (kelompok yang diberi nanas).

\section{HASIL PENELITIAN}

Jumlah sampel yang terlibat dalam penelitian ini adalah 62 orang yang terdiri atas 43 sampel berjenis kelamin perempuan dan 19 sampel berjenis kelamin laki-laki. Umur pada sampel penelitian bervariasi antara 17 sampai 21 tahun. Distribusi karakteristik responden dapat dilihat dari tabel 1.

\section{A. Gambaran hasil pH saliva responden}

Hasil pemeriksaan $\mathrm{pH}$ saliva pada responden setelah mengkonsumsi minuman berkarbonasi, baik kelompok kontrol maupun kelompok perlakuan diperoleh hasil rata-rata sebagai berikut: 
Tabel 1. Distribusi karakteristik responden

\begin{tabular}{lcc}
\hline Responden & Jml & $\%$ \\
\hline Usia & & \\
17 tahun & 5 & $8,1 \%$ \\
18 tahun & 16 & $25,8 \%$ \\
19 tahun & 24 & $38,7 \%$ \\
20tahun & 16 & $25,8 \%$ \\
21 tahun & 1 & $1,6 \%$ \\
\hline Jenis kelamin & & \\
Perempuan & 43 & $64,2 \%$ \\
Laki-laki & 19 & $35,7 \%$ \\
\hline Angkatan & & \\
2016 & 25 & $40,3 \%$ \\
2017 & 21 & $33,9 \%$ \\
2018 & 16 & $25,8 \%$ \\
\hline
\end{tabular}

Tabel 2. Gambaran pH saliva responden setelah mengkonsumsi minuman berkarbonasi

\begin{tabular}{ccc}
\hline Kelompok & Mean & SD \\
\hline Kontrol & 6,5658 & 0,22 \\
Perlakuan & 6,4397 & 0,29 \\
\hline
\end{tabular}

Berdasarkan tabel 2, didapatkan rata-rata $\mathrm{pH}$ saliva kelompok kontrol adalah 6,5658 $\pm 0,22$ dan rata-rata kelompok perlakuan adalah
$6,4397 \pm 0,29$ dengan perbedaan (selisih) ratarata kedua kelompok 0,1261.

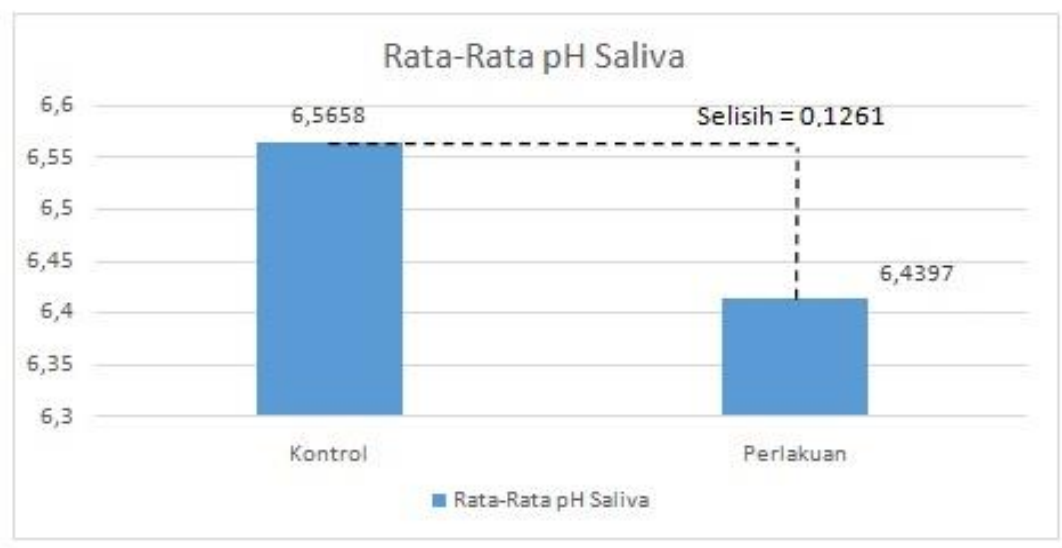

Gambar 1 : Perbedaan nilai rata-rata pH saliva kelompok kontrol dan kelompok perlakuan sebelum mendapat perlakuan.

Tabel 3 : Gambaran pH saliva kelompok kontrol dan perlakuan setelah mendapat perlakuan.

\begin{tabular}{ccc}
\hline Kelompok & Mean & SD \\
\hline Kontrol & 6,8077 & 0,24 \\
Perlakuan & 7,2800 & 0,28 \\
\hline
\end{tabular}




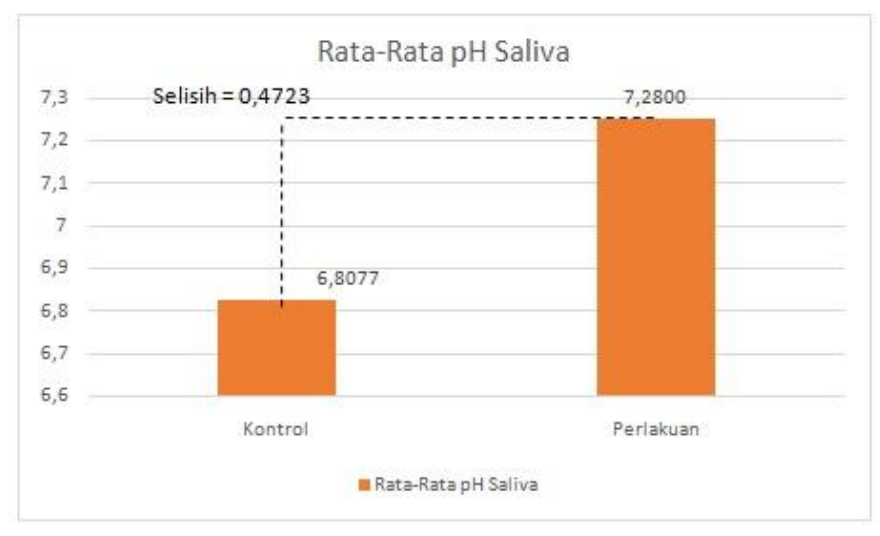

Gambar 2 : Perbedaan nilai rata-rata pH saliva kelompok kontrol dan kelompok perlakuan setelah mendapat perlakuan

Tabel 4 : Rata - rata hasil pH saliva

\begin{tabular}{|c|c|c|c|c|}
\hline \multirow{3}{*}{$\begin{array}{c}\text { Rata- } \\
\text { rata }\end{array}$} & \multicolumn{2}{|c|}{ Pair 1} & \multicolumn{2}{|l|}{ Pair 2} \\
\hline & Kontrol Karbonasi & Kontrol & Perlakuan Karbonasi & Perlakuan \\
\hline & 6.5658 & 6.8077 & 6.4397 & 7.2800 \\
\hline
\end{tabular}

Berdasarkan tabel 3. didapatkan rata-rata $\mathrm{pH}$ saliva kelompok yang menjadi kontrol adalah $6,8077 \pm 0,24$ dan rata-rata kelompok perlakuan adalah $7,2800 \pm 0,28$ dengan perbedaan (selisih) rata-rata kedua kelompok 0,4723 .

\section{Pengaruh mengkonsumsi buah nanas (Ananas Comosus L. Merr) terhadap pH saliva}

Uji T berpasangan (Paired Samples TTest) dilakukan untuk menguji hipotesis dalam penelitian ini. Uji T berpasangan di pakai untuk mencari ada atau tidaknya perbedaan rata-rata pH saliva kelompok kontrol setelah mengkonsumsi karbonasi karbonasi dengan kelompok kontrol dan kelompok perlakuan setelah mengkonsumsi karbonasi dengan kelompok perlakuan. Kemudian dilanjutkan dengan uji Independent Sample T-Test untuk mencari perbedaan rata-rata peningkatan (selisih) $\mathrm{pH}$ kelompok kontrol (kontrol karbonasi-kontrol) dengan kelompok perlakuan (perlakuan karbonasi- perlakuan).

Pada tabel 4 , tampak nilai rata-rata $\mathrm{pH}$ saliva kelompok kontrol karbonasi adalah 6,5658 sedangkan kelompok kontrol adalah 6,8077 . Nilai rata-rata $\mathrm{pH}$ saliva kelompok perlakuan karbonasi adalah 6,4397 sedangkan kelompok perlakuan 7,2800 .

Tabel 5 : Uji Statistic Paired Samples T-Test

\begin{tabular}{cccccc}
\hline & Kelompok & Mean & Selisih & Std. Deviation & $p-$ value \\
\hline Pair 1 & Kontrol Karbonasi - Kontrol & 0.24194 & 0.2419 & 0.08811 & 0,000 \\
\hline Pair 2 & $\begin{array}{c}\text { Perlakuan Karbonasi- } \\
\text { Perlakuan }\end{array}$ & 0.84032 & 0.8403 & 0.25472 & 0,000 \\
\hline
\end{tabular}


Pada tabel 5, tampak nilai rata-rata pair 1 adalah 0,24194 $\pm 0,08811$ ( $p$-value 0,00$)$ dengan selisih rata-rata 0,2419 dan pair 2 $0,84032 \pm 0,25472$ (p-value 0,00) dengan selisih rata-rata 0,84032 . Jika nilai $p-$ value $\leq$
0,05 yang berarti terdapat perbedaan antara variabel, sedangkan jika nilai $p-$ value bernilai > 0,05 berarti tidak terdapat perbedaan antar variabel.

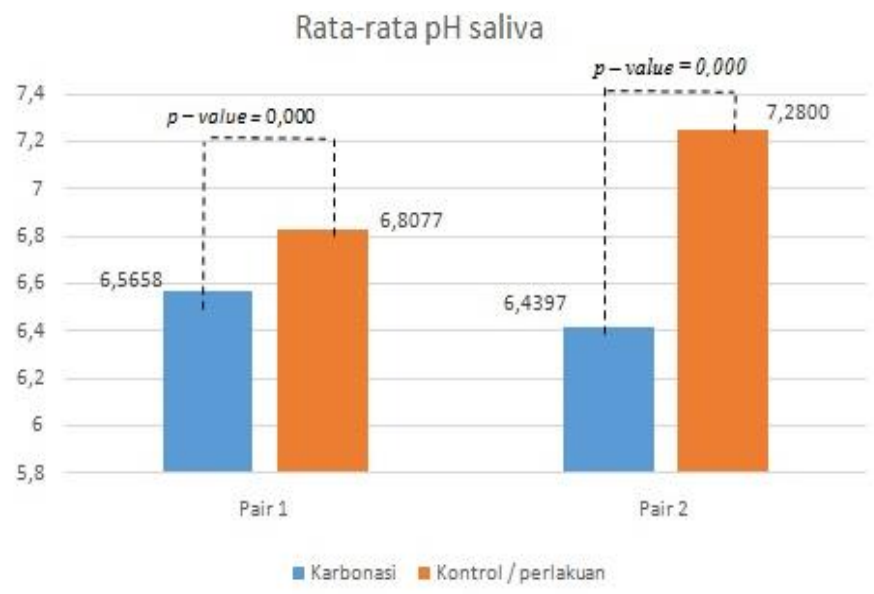

Gambar 3 : Perbedaan nilai rata-rata pH saliva pair 1 dan pair 2

Tabel 6: Uji Independent Sample T-Test Selisih pH Kelompok kontrol dan Perlakuan

\begin{tabular}{|c|c|c|c|c|c|}
\hline & kelompok hasil & $N$ & Mean & Std. Deviation & $P$-value \\
\hline \multirow{2}{*}{ Selisih $p H$} & kelompok kontrol & 31 & 0.2419 & 0.08811 & 0.000 \\
\hline & kelompok perlakuan & 31 & 0.84032 & 0.25472 & 0.000 \\
\hline
\end{tabular}

Berdasarkan tabel 6 penentuan hipotesis uji T berpasangan diterima jika nilai $p$-value $\leq 0,05$ yang berarti terdapat perbedaan antar kelompok kontrol dan perlakuan namun, jika nilai $p$-value $>0,05$ berarti tidak terdapat kelompok perlakuan. Gambar 4, menunjukan nilai $p$-value $\leq 0,05$ dengan perbedaan rata-rata kedua kelompok adalah 0,59838 ( $p$-value = 0,000).

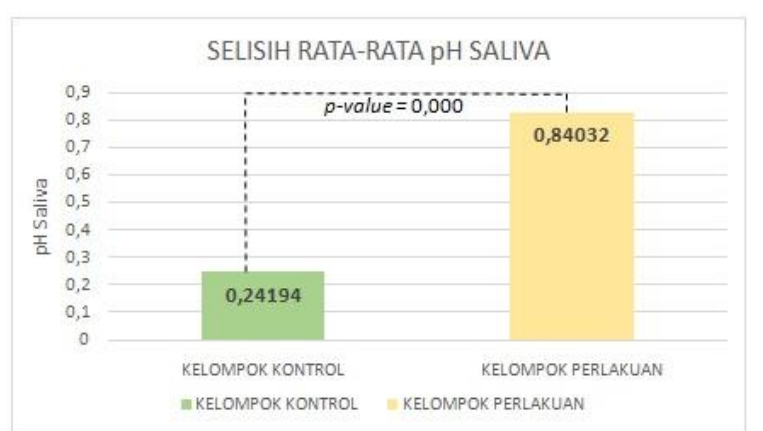

Gambar 4 : Perbedaan nilai rata-rata $\mathrm{pH}$ saliva kelompok kontrol dan kelompok perlakuan

Dari hasil pengukuran $\mathrm{pH}$ yang di dapatkan dilakukan pengujian dengan menggunakan uji Statistic Paired Samples T- 
Test untuk mencari ada atau tidaknya perbedaan rata-rata $\mathrm{pH}$ saliva kontrol karbonasi - kontrol dan $\mathrm{pH}$ saliva perlakuan karbonasi perlakuan. Kemudian dilanjutkan dengan uji Independent Sample T-Test untuk mencari perbedaan rata-rata peningkatan (selisih) $\mathrm{pH}$ kelompok kontrol (kontrol karbonasi - kontrol) dengan kelompok perlakuan (perlakuan karbonasi - perlakuan). Hasil dari penelitian ini menunjukkan terdapat perbedaan bermakna pada uji Statistic Paired Samples T-Test dan Independent Sample T-Test antara kelompok perlakuan dan kelompok kontrol dengan nilai $p$ value $=0,000$, maka dapat disimpulkan bahwa terdapat pengaruh konsumsi buah nanas (Ananas Comosus L. Merr) terhadap pH saliva setelah mengkonsumsi minuman berkarbonasi.

Penelitian ini menunjukan bahwa pengkonsumsian buah nanas sebanyak 100 gram dapat mempengaruhi $\mathrm{pH}$ saliva setelah mengkonsumsi minuman berkarbonasi, dimana konsumsi minuman berkarbonasi bertujuan untuk menurunkan $\mathrm{pH}$ saliva sehingga peningkatan (selisih) $\mathrm{pH}$ saliva dari kelompok yang mengkonsumsi buah nanas dan tidak mengkonsumsi buah nanas dapat jelas terlihat. Pengupasan buah nanas yang di pakai dalam penelitian dilakukan 2 jam sebelum penelitian ditimbang dan dimasukan ke dalam plastik zipper dan disimpan dalam box container berisi es batu sehingga enzim atau kandungan buah nanas tidak rusak, baik, bersih dan aman untuk dikonsumsi.

Hasil dari pengukuran $\mathrm{pH}$ saliva setelah mengkonsumsi minuman berkarbonasi pada penelitian ini sesuai dengan hasil penelitian Aritonang tahun 2014 dimana terdapat hubungan frekuensi minum softdrink terhadap $\mathrm{pH}$ saliva yang di pengaruhi oleh frekuensi konsumsi, lama konsumsi, cara konsumsi, kandungan minuman karbonasi dan perilaku setelah konsumsi minuman berkarbonasi, dimana semakin tinggi frekuensi mengkonsumsi minuman softdrink maka semakin rendah angka $\mathrm{pH}$ saliva. ${ }^{5}$ Penelitian Rahmawati tahun 2015 menyimpulkan bahwa mengkonsumsi minuman berkarbonasi yang terlalu banyak dalam sehari akan mengakibatkan penurunan $\mathrm{pH}$ saliva dibawah normal karena minuman berkarbonasi mengandung karbohidrat dan gula yang akan difermentasi menjadi asam oleh mikroorganisme rongga mulut. ${ }^{4}$ Penelitian Adi Putra Rakhmanda tahun 2008 tentang perbandingan efek antibakteri jus nanas (Ananas Comosus L. Merr) pada berbagai konsentrasi terhadap Streptococcus mutans menjelaskan, bakteri Streptococcus mutans merupakan bakteri flora normal yang paling banyak menyebabkan karies, karena kemampuannya yang dapat memfermentasi karbohidrat (sukrosa, fruktosa dan glukosa) menjadi asam yang mengakibatkan turunnya pH saliva. ${ }^{2}$ Namun pada hasil pengukuran $\mathrm{pH}$ saliva kelompok yang mengkonsumsi minuman berkarbonasi ditemukan ketidaksamaan. Hal ini dapat disebabkan oleh proses minum yang tidak sama sehingga minuman berkarbonasi tidak mengenai seluruh permukaan rongga mulut yang mengakibatkan proses fermentasi yang dilakukan flora normal sama.

Hasil perhitungan statistik $\mathrm{pH}$ saliva menunjukkan terdapat pengaruh konsumsi buah nanas (Ananas Comosus L. Merr) terhadap $\mathrm{pH}$ saliva setelah mengkonsumsi minuman berkarbonasi. Hasil ini sesuai dengan hasil penelitian Cahyo Nugroho tahun 2016, tentang pengaruh mengkonsumsi buah nanas (Ananas Comosus L. Merr) terhadap pH saliva 
pada anak santriwati usia 12-16 tahun Pesantren Perguruan Sukahideng Kabupaten Tasikmalaya dimana terdapat pengaruh mengkonsumsi buah nanas terhadap keasaman mulut dan mengembalikan $\boldsymbol{p H}$ saliva ke level aman yaitu 6,8-7,2. ${ }^{1}$ Namun pada hasil pengukuran $\mathrm{pH}$ saliva kelompok yang mengkonsumsi buah nanas ditemukan ketidaksamaan $\mathrm{pH}$. Hal ini dapat disebabkan oleh proses pengunyahan dan pengecapan yang terlalu cepat ataupun terlalu lambat, sehingga laju aliran saliva yang terjadi pada tiap sampel berbeda.

Buah nanas (Ananas Comosus L. Merr) terbukti dapat meningkatkan $\mathrm{pH}$ saliva karena mengandung serat yang tinggi. Peningkatan tersebut terjadi karena adanya stimulasi pengunyahan dan pengecapan secara serentak pada saat mengkonsumsi buah nanas yang mengakibatkan terjadinya peningkatan laju aliran saliva. ${ }^{6}$ Asam sitrat yang terkandung di dalam buah nanas dapat meningkatkan sekresi saliva. Hal ini sejalan dengan teori yang menyatakan bahwa stimuli asam merupakan stimulator kuat dalam merangsang sekresi saliva dibandingkan dengan stimulasi mekanis. Rangsangan pengecapan seperti dengan rangsangan rasa asam dapat merangsang sekresi saliva dalam jumlah yang sangat banyak seringkali 8 sampai 20 kali kecepatan sekresi basal. ${ }^{7}$ Peningkatan laju aliran saliva berbanding lurus dengan peningkatan $\mathrm{pH}$ saliva, Sehingga jika terjadi peningkatan laju aliran saliva maka $\mathrm{pH}$ saliva akan ikut meningkat. Selain itu, buah nanas juga mengandng enzim bromelin yang berfungsi menghambat pertumbuhan bakteri flora normal penghasil asam, jika proses fermentasi dapat di kendalikan maka pH saliva akan dapat kembali ke titik normal lebih cepat. ${ }^{8}$.

\section{KESIMPULAN}

Terdapat perbedaan nilai rata-rata $\mathrm{pH}$ saliva responden yang mendapat perlakuan dan kontrol. Terdapat pengaruh konsumsi buah nanas (Ananas Comosus L. Merr) terhadap pH saliva setelah mengkonsumsi minuman berkarbonasi, dengan perbedaan rata-rata kedua kelompok adalah 0,59838 ( $p$-value $=$ $0,000)$.

\section{SARAN}

Masyarakat disarankan untuk mengkonsumsi buah nanas setelah mengkonsumsi makanan dan minuman yang mengandung karbohidrat (sukrosa, fruktosa dan glukosa) untuk menjaga kebersihan dan kesehatan rongga mulut dan terhindar dari pembentukan karies pada gigi.

\section{REFERENSI}

1. Nugroho C. Pengaruh mengkonsumsi buah nanas terhadap ph saliva pada anak santriwati usia 12-16 tahun pesantren perguruan sukahideng kabupaten tasikmalaya. 2016.

2. Rakhmanda A. Perbandingan efek antibakteri jus nanas (Ananas comosus (L) Merr.) Pada berbagai konsentrasi terhadap Streptococcus mutans. 2008.

3. Muthu, MS . Sivakumar N. Pediatric dentistry principles and practice. Elsevier. 2009:198.

4. Ida Rahmawati. Fahmi said. Perbedaan ph saliva antara sebelum dan sesudah mengkonsumsi minuman ringan. J Skala Kesehat. 2014;6.

5. Aritonang I. Hubungan frekuensi minum soft drink terhadap ph saliva dan angka dmf-t pada siswa/i kelas xi ipa man 2 model jalan williem iskandar no.7a kec. Medan Tembung Tahun 2014. J IIm PANNMED. 2014:9. 
6. Indriana. T. Perbedaan laju aliran saliva dan ph karena pengaruh stimulus kimiawi dan mekanis. $J$ Kedokt Meditek Univ Jember. 2011;7.

7. S HP. Pengaruh berkumur larutan ekstrak bonggol nanas (ananas comosus (I .) merr.) terhadap peningkatan ph saliva rongga mulut. Fak Kedokt Gigi Univ Hasanuddin. 2016.

8. Nila K. Fisiologi Dan Patologi Saliva. Padang: Andalas University Press; 2015. 